\title{
Conversion of Inorganic Selenium to Organic Form(s) by Lactobacillus acidophilus
}

\author{
Zommara, M.A.(1) \& Prokisch, J.(2) \\ (1) Department of Dairy Science, Fac. of Agric., Kafrelsheikh University, Kafr El-Sheikh, 33516, Egypt. \\ (2) Nanofood Laboratory, Fac.of Agric. and Food Sciences and Environmental Management, Debrecen \\ University H-4032 Debrecen, Hungary.
}

Received: 16 July, 2019

Revised: 15 October, 2019

Accepted: 18 November, 2019

\begin{abstract}
The bioconversion of 2 forms of inorganic selenium namely selenite (SeIV) and selenate (SeVI) to organic form(s) by Lactobacillus acidophilus strain was investigated. The cultured media (MRS) was supplemented with 1, 2, 5, 10, $20 \mathrm{ppm}$ of $\mathrm{Se}$ in the form of sodium selenite $\left(\mathrm{Na}_{2} \mathrm{SeO}_{3}, \mathrm{SeIV}\right)$ or sodium selenate $\left(\mathrm{Na}_{2} \mathrm{SeO}_{4}, \mathrm{SeVI}\right)$ and incubated at $37^{\circ} \mathrm{C}$ up to $24 \mathrm{hr}$ Both Se forms showed no marked effect on the bacterial growth indicating no cytotoxicity at these concentrations. However, the media supplemented with 5, 10 and $20 \mathrm{ppm}$ of $\mathrm{Se}(\mathrm{IV})$, but not $\mathrm{Se}(\mathrm{VI})$, became reddish after $24 \mathrm{hr}$ of incubation with increasing the red color intense with increasing the Se content in the media. The scanning electron microscope (SEM) investigation clarified the presence of Se-nano particles (SeNPs) in the media. Se speciation of the cultured media supernatant and its corresponding cell fractions using HPLC-ICP-MS technique indicated that the bioconversion rate of Se to organic form(s) was extremely higher in $\mathrm{Se}(\mathrm{IV})$ than $\mathrm{Se}(\mathrm{VI})$ in both fractions however, the cell fractions contained the highest content. The organic Se gradually increased in both fractions with increasing the media Se content. The inorganic Se was completely bio-converted to organic form(s) without any residual only in the medium contained $1 \mathrm{ppm}$ Se(IV). Our results demonstrate the ability of $L$. acidophilus to convert $\mathrm{Se}(\mathrm{IV})$ but not $\mathrm{Se}(\mathrm{VI})$, at a limit concentration of $1 \mathrm{ppm}$ and accumulate organic Se form(s) in the cell fraction. These results confirm the possible bio-production of organic Se enriched fermented dairy products.
\end{abstract}

Keywords: Bioremediation, organic selenium, inorganic selenium, L. acidophilus, nanoselenium

\section{INTRODUCTION}

The role of selenium for the maintenance of health and prevention of several diseases is probably more important than realized previously. Besides, its putative role as a protecting agent against heavy metal toxicity, cancer, and cardiovascular diseases selenium is now linked to a number of physiological functions. Young children have an increased selenium requirement because of their rapid growth and they could be, therefore, at greater risk in the case of inadequate intake. The recommended safe and adequate intake level of $50 \mu \mathrm{g} /$ day was defined by the National Research Council in the USA. On the other hand, several studies have been shown repeatedly that $\mathrm{Se}$ is more bioavailable to animals and humans in organic forms than in inorganic forms.

The selenium content of food depends upon the selenium content of the soil where the animal was raised or the plant grown. The Egyptian soil and plants content of Se is generally low and con- sidered among the low-Se countries (Jansson and Sillanpää, 1992. Elsokkary (1980) determined the Se content of 55 soil samples collected from different parts in Egypt. The results vary from 0.18 to $0.85 \mathrm{ppm}$ with an average of $0.45 \mathrm{ppm}$. The selenium intake in Egypt is sufficient, to some extent, because of the high-selenium wheat imported from North America. The estimated Se intake for the Egyptian adult is about $49 \mu \mathrm{g} /$ day where bread supplies about $63.6 \%$ of the daily consumed Se (Hussein \& Bruggeman, 1999). This situation could change because of more home-grown wheat production in recent years. Therefore, the search for other sources of selenium is very important to compensate for the expected shortage of selenium in the Egyptian diet.

Lactic acid bacteria (LAB) is an important part of diet in the form of fermented food products in different parts of the world and their biotransformation ability gives a cheap source of organic Se for human and animal nutrition (Zommara and 
Prokisch, 2015, Pophaly et al., 2014). Different LAB strains were found to have the ability to accumulate organic selenium and elemental SeNPs in their bodies and media when cultivated with inorganic Se forms. This characteristic is very valuable as several LAB strains are in use for producing many fermented dairy products. Therefore, such ability gives a cheap source of organic Se for human and livestock nutrition.

The aim of the present study is to investigate the ability of Lactobacillus acidophilus to bioconvert two inorganic selenium compounds to organic form(s) when grown on MRS medium supplemented with different doses of selenite (SeIV) or selenate (SeVI).

\section{MATERIALS AND METHODS}

\section{Cultivation of Lactobacillus acidophilus with selenium}

Pure culture of Lactobacillus acidophilus ( $L$. acidophilus) NCAIM B 02085 strain was obtained from the National Collection of Agricultural and Industrial Microorganisms, Budapest, Hungary. The bacterial culture was cultivated in MRS broth medium as described by De-Man et al., (1960) amended with $0,1,2,5,10$ and $20 \mathrm{ppm}$ of filter sterilized (Sartorius AG, Germany) sodium selenite, $\mathrm{Na}_{2} \mathrm{SeO}_{3} .5 \mathrm{H}_{2} \mathrm{O}$ [Se(IV)], or sodium selenate, $\mathrm{Na}_{2} \mathrm{SeO}_{4} \cdot 10 \mathrm{H}_{2} \mathrm{O}$ [Se(VI)] Sigma-Aldrich, Switzerland) and incubated at $37^{\circ} \mathrm{C}$ up to $24 \mathrm{hr}$.

\section{Determination of bacterial growth}

The bacterial growth was monitored at $2 \mathrm{hr}$ intervals for $12 \mathrm{hr}$ and after $24 \mathrm{hr}$ of incubation the cultured media. The bacterial growth was determined by measuring the media absorbance at 650 $\mathrm{nm}$ (Loualeche et al., 1993) and changes in medium $\mathrm{pH}$ value (Radelkis Electrochemical Instruments, Hungary).

\section{Analysis of selenium species in medium supernatant and cell fraction}

Ten $\mathrm{ml}$ aliquots of media were removed after $24 \mathrm{hr}$ of incubation. The media were centrifuged at $4500 \mathrm{~g}$ (7000 rpm) for $20 \mathrm{~min}$ at $10^{\circ} \mathrm{C}$ to spin down the bacterial cells. The supernatant was carefully collected and kept under freezing for Se speciation analysis. The cell pellets were washed 2 times by Tris-HCl buffer $(50 \mathrm{mM}, \mathrm{pH} 7.5)$ and finally with ultra-pure water. To the cell pellet $1 \mathrm{ml}$ Tris- $\mathrm{HCl}$ buffer (10 mM, pH 8.0) was added followed by $100 \mu 1$ of $10 \%$ lysozyme solution (Sigma-Aldrish, $100.000 \mathrm{U} / \mathrm{mg}$ ) and incubated overnight at room temperature. The hydrolyzed cell pellet was centrifuged at $5000 \mathrm{~g}$ for $20 \mathrm{~min}$ and the supernatant was collected (cell fraction) for Se speciation analysis.

Media supernatant and the cell fractions were analyzed for Se species by inductively coupled plasma mass spectrometer (ICP-MS) (X series, Thermo Fisher Scientific, Germany) coupled to HPLC (Merk-Hitachi L06200A, Germany) equipped with an anion exchange chromatography column (Polyspher, IC-ANI, Merck, Germany) as previously described (Zommara et al., 2007). Se standards namely, seleno-L-methionine (SeMet, Fluka Chemie, Switzerland), SeIV and SeIV were prepared in Milli-Q water.

\section{Scanning Electron Microscopy (SEM) and SeNPs size determination}

The SEM of the bacterial medium was carried out according to Nagy et al., (2016) using Hitachi S 4300 scanning electron microscope (Schaumburg, IL, USA). Size of the SeNPs was determined by particle size analyzer (Malvern, Mastersizer 2000) Malvern Instruments Ltd, UK.

\section{RESULTS AND DISCUSSION}

Data illustrated in Fig. (1) and Fig. (2) show the growth profile of L.acidophilus strain incubated in MRS media with different concentration of Se(IV). The bacterial growth rate was monitored during $24 \mathrm{hr}$ of incubation using the progress of medium acidity and absorbance as viability indications. The $\mathrm{pH}$ data indicated no inhibition effect of Se(IV) on bacterial growth up to $5 \mathrm{ppm}$ in the medium. However, addition of 10 and $20 \mathrm{ppm}$ to the medium had a slight negative effect on bacterial growth. The media absorbance confirmed the $\mathrm{pH}$ data although the media amended with 10 and 20 ppm Se(IV) resulted in high absorbance after $4 \mathrm{hr}$ of incubation compared to the media with less Se(IV) content. This increase may be explained by accumulation of red selenium nano-particles (SeNPs) in the media (Fig. 3). The scanning electron microscope (SEM) photo of the medium amended with $20 \mathrm{ppm}$ Se(IV) showed the accumulation of SeNPs in the cultured medium and inside the bacterial cells (Fig. 4). In this respect, Alzate et al. (2010) stated that supplementation of milk with Se(IV) below 2 ppm had no negative effect in the growth of a mixed cultures 


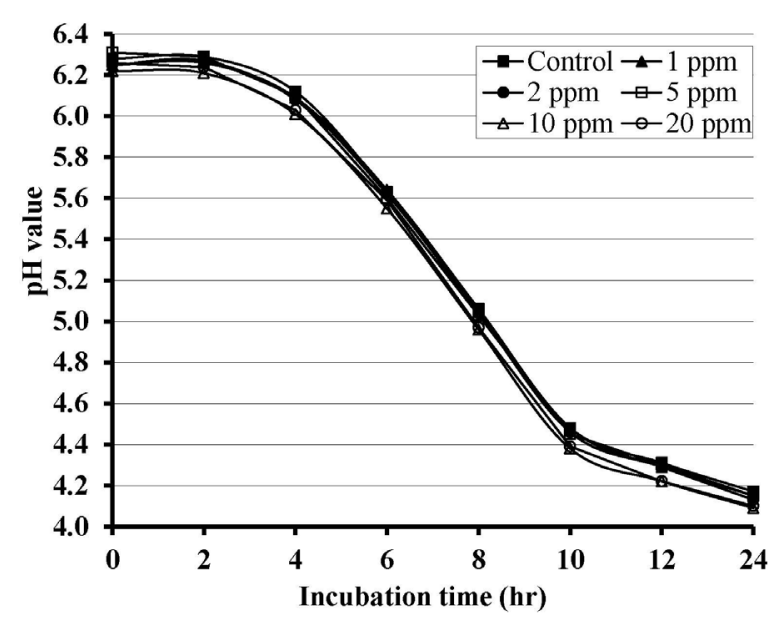

Fig. (1): Effect of selenium (Se IV) concentration on $\mathrm{pH}$ of MRS broth media incubated with $L$. acidophilus at $37^{\circ} \mathrm{C}$ for $24 \mathrm{hrs}$.

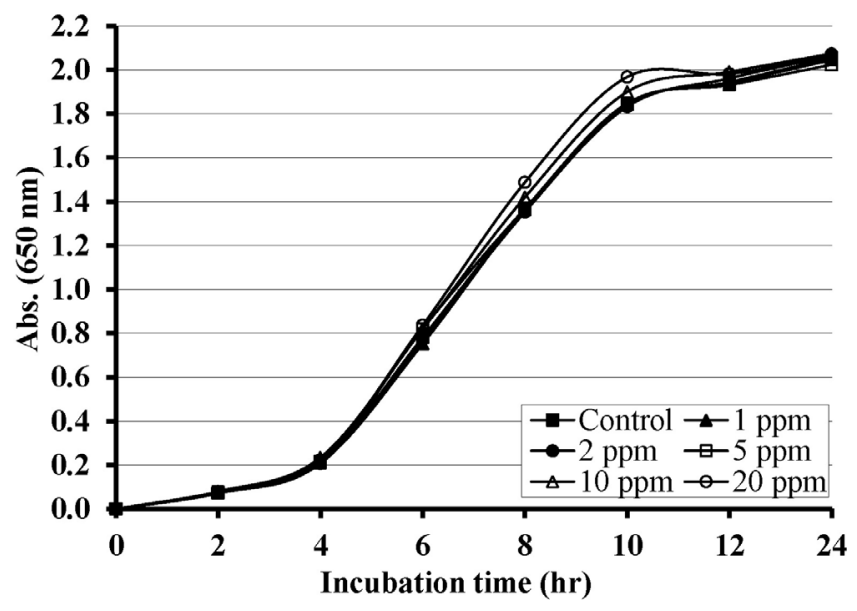

Fig. (2): Effect of selenium (Se IV) concentration on growth of $L$. acidophilus incubated in MRS broth media at $37^{\circ} \mathrm{C}$ for $24 \mathrm{hrs}$.
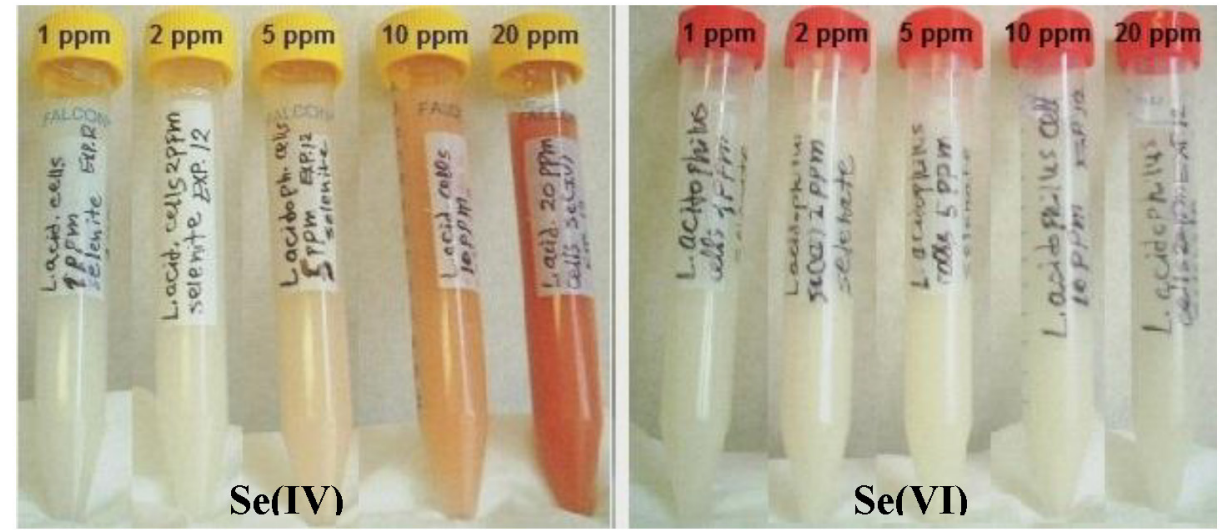

Fig. (3): Accumulation of red SeNps in MRS media cultivated with $L$. acidophilus and $20 \mathrm{ppm}$ of Se (IV) after $24 \mathrm{hr}$ of incubation at $37^{\circ} \mathrm{C}$

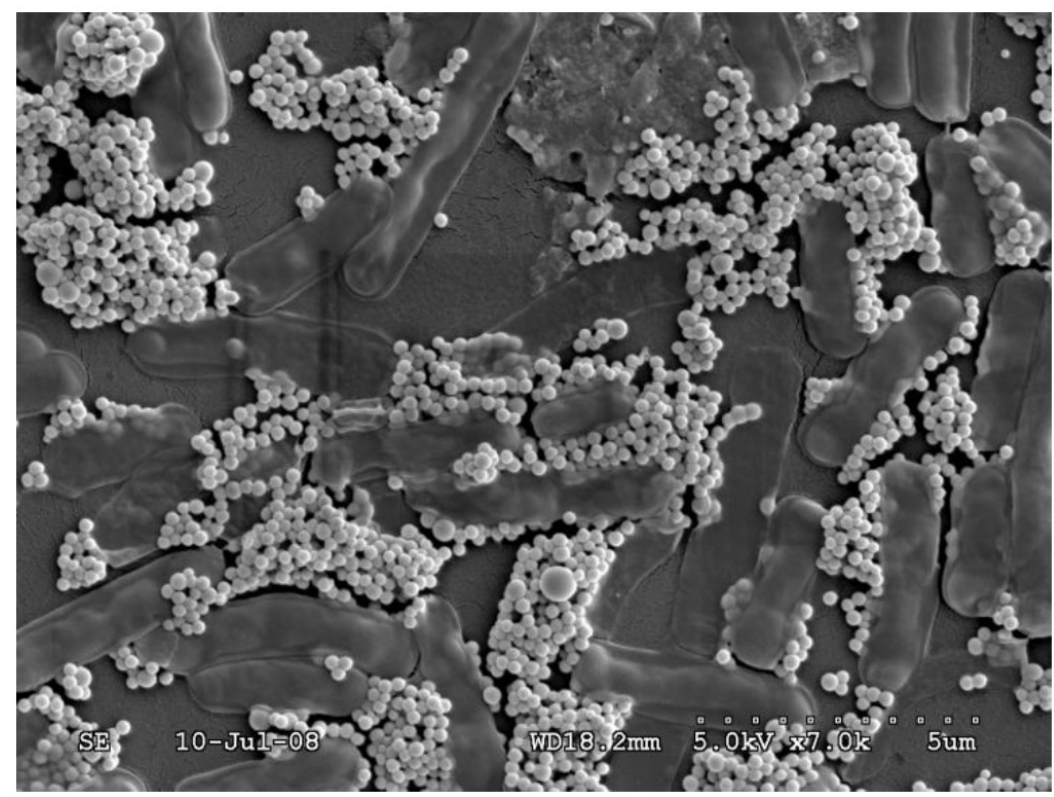

Fig. (4): Scanning electron microscope (SEM) photo of (SeNps) in MRS media cultivated with L. acidophilus and $20 \mathrm{ppm}$ of $\mathrm{Se}(\mathrm{IV})$ after $24 \mathrm{hr}$ of incubation at $37^{\circ} \mathrm{C}$. 
of S. thermophilus, L. bulgaricus, L. acidophilus, L. paracasei and B. Lactis until the 4th week of cold storage. They noticed segregated selenium as SeNPs in the fermented milk supplemented with 6 , 10 and 20 ppm SeIV. Also, different LAB and bifidobacteria were found to accumulate SeNPs when cultivated in suitable media amended with different concentrations of SeIV (Prokisch \& Zommara, 2011).

Our previous studies showed no inhibition effect of SeIV on the traditional yoghurt culture (S. thermophilus and L. bulgaricus) up to $20 \mathrm{ppm}$ (Zommara \& Prokisch, 2015). On the other hand, there was no inhibition effect of $\mathrm{Se}(\mathrm{VI})$ on the growth of L. acidophilus as indicated by following the media pH (Fig. 5) and absorbance (Fig. 6) although, the bacterial growth rate was slightly lower than that cultivated with $\mathrm{Se}(\mathrm{IV})$. Unlike $\mathrm{Se}(\mathrm{IV})$, use of $\mathrm{Se}(\mathrm{VI})$ did not led to accumulate the red SeNPs in the media (Fig. 3). The ability of lactic acid bacteria to bio-transform selenium Se (IV) to organic form(s) have been reported in plenty of research papers including different strains of lactobacilli and the traditional yoghurt starter culture (Prokisch et al., 2008, Pophaly et al., 2014, Zommara \& Prokisch, 2015, Kurek, et al., 2016, Pescuma et al., 2017)

The formation of organic selenium takes place by replacing sulfur with Se in the sulfide amino acids in the proteins namely cysteine and methionine to form selenocysteine (Se-cys) and selenomethionine (Se-met) as the main organic selenium species found in plant and animal tissue (Alzate et al., 2007, Alzate et al., 2008, Galano et al., 2013, Palomo et al., 2014, Zommara \& Prokisch, 2015, Pes-

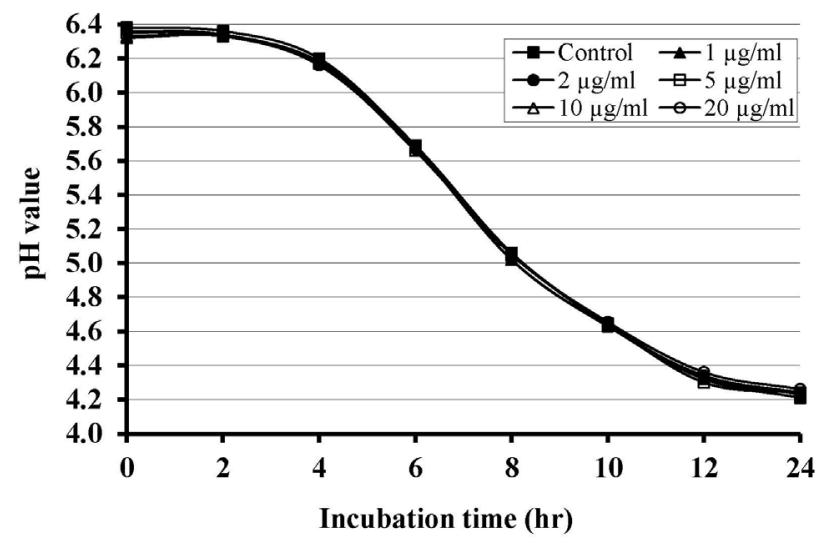

Fig. 5: Effect of selenium Se (VI) concentration on pH of MRS broth media incubated with $L$. acidophilus at $37^{\circ} \mathrm{C}$ for $24 \mathrm{hrs}$. cuma et al., 2017). Also, the production of SeNPs by $L$. acidophilus cultivated in suitable medium supplemented with $\mathrm{Se}(\mathrm{IV})$ was repeatedly confirmed by many researchers (Eszenyi et al 2011, Rajasree \& Gayathri, 2015, Nagy et al., 2016). Our results demonstrated that Lactobacillus acidophilus produce SeNPs with 100-200 nm dimeter when cultivated with MRS media amended with Se (IV). Diowksza et al., (1999) also observed a red color in L. plantarum, L. brevis, L. sanfrancisco biomass grown in MRS medium amended with Se(IV) exceeding $10 \mathrm{ppm}$. The formation of SeNPs by the bacterial cultures may be attributed to a detoxification mechanism (Prokisch et al., 2008).

In this respect, Zhang et al., (2004) studied the effect of different size of SeNPs (5-200 nm) on the induction of seleno-enzymes, namely, glutathione peroxidase (GPx), phospholipid hydroperoxide glutathione peroxidase (PhGPx) and thiredoxin reductase (TrxR) in mice and liver cell HepG2. They found no significant size effect and all nanoSe particles have equal capacity in the induction of the tested seleno-enzymes. However, Peng et al., (2007) suggested that Nano-Se should be most effective as a chemopreventive agent at smaller particle size. They stated that the SeNPs size effect may depend on the Se status in the cell and suggested that in Se deficiency, cells may up regulate different effective pathways for Se uptake, leading to no size effect of SeNPs on the synthesis of selenoenzymes.

The ability of $L$. acidophilus to convert different concentrations of Se(IV) to organic form in MRS media is shown in Fig. (7) and Fig. (8). The data in Fig. (7) clearly show that most of Se(IV)

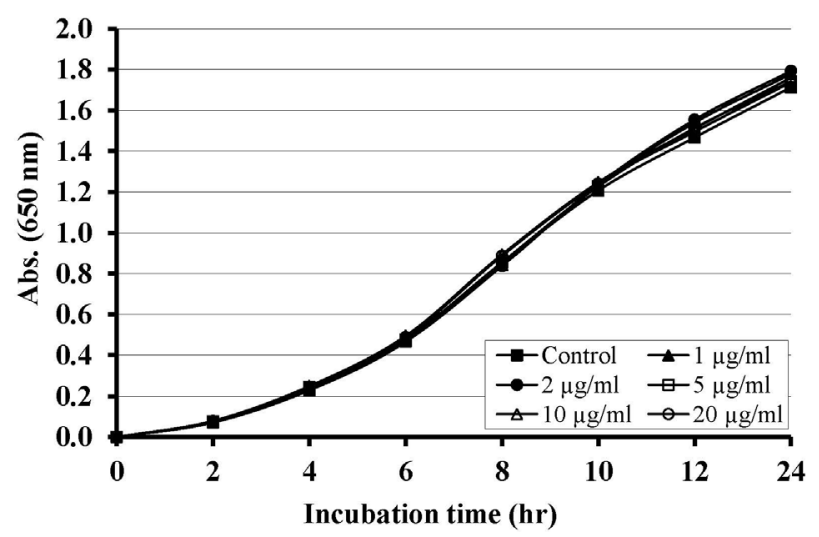

Fig. 6: Effect of selenium Se (VI) concentration on growth of $L$. acidophilus incubated in MRS broth media at $37^{\circ} \mathrm{C}$ for $24 \mathrm{hrs}$ 


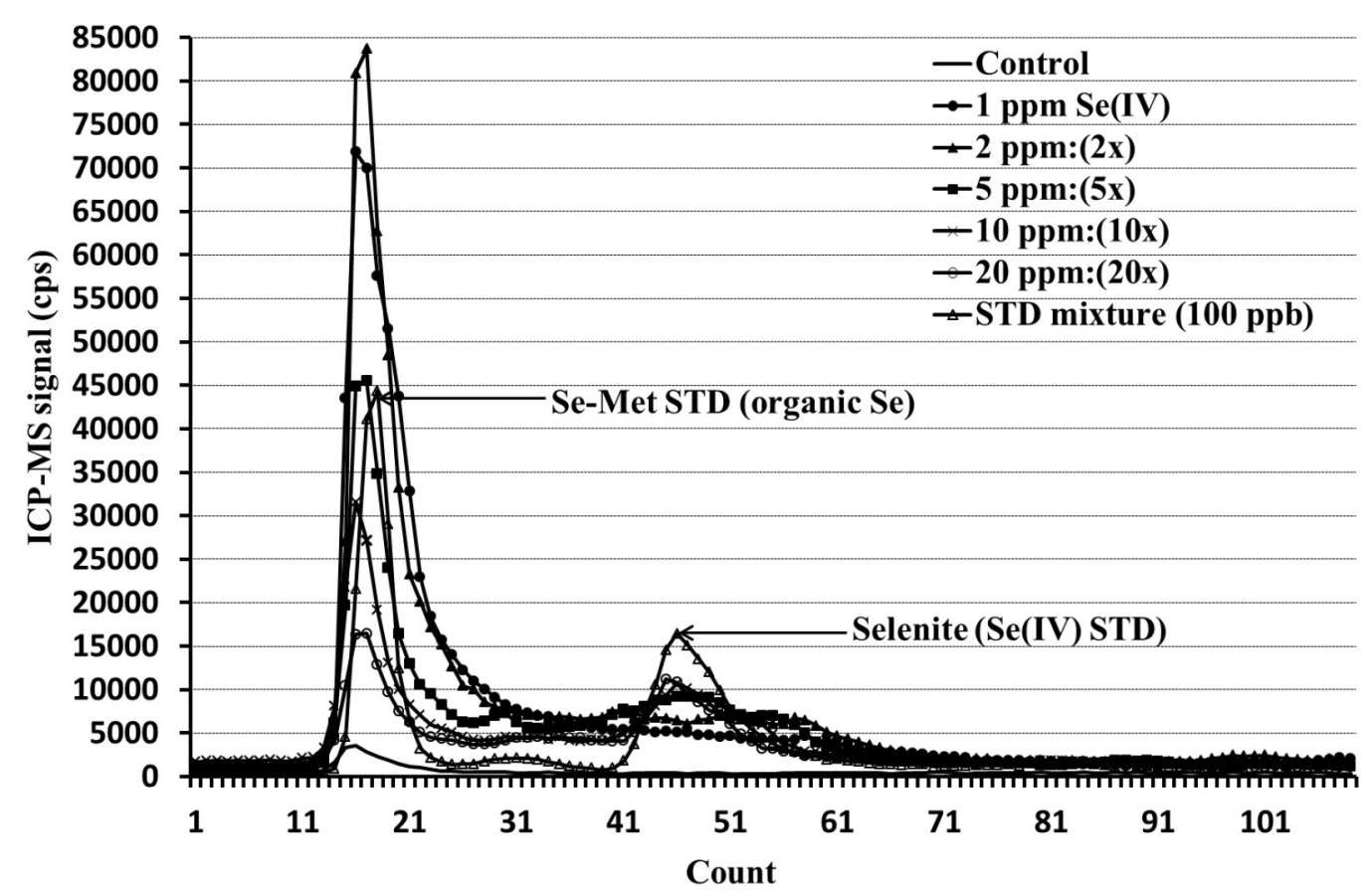

Fig. 7: Conversion of different concentrations of sodium selenite [Se(IV)] to organic form in MRS media supernatant incubated with L. acidophilus at $37^{\circ} \mathrm{C}$ for $24 \mathrm{hrs}$.

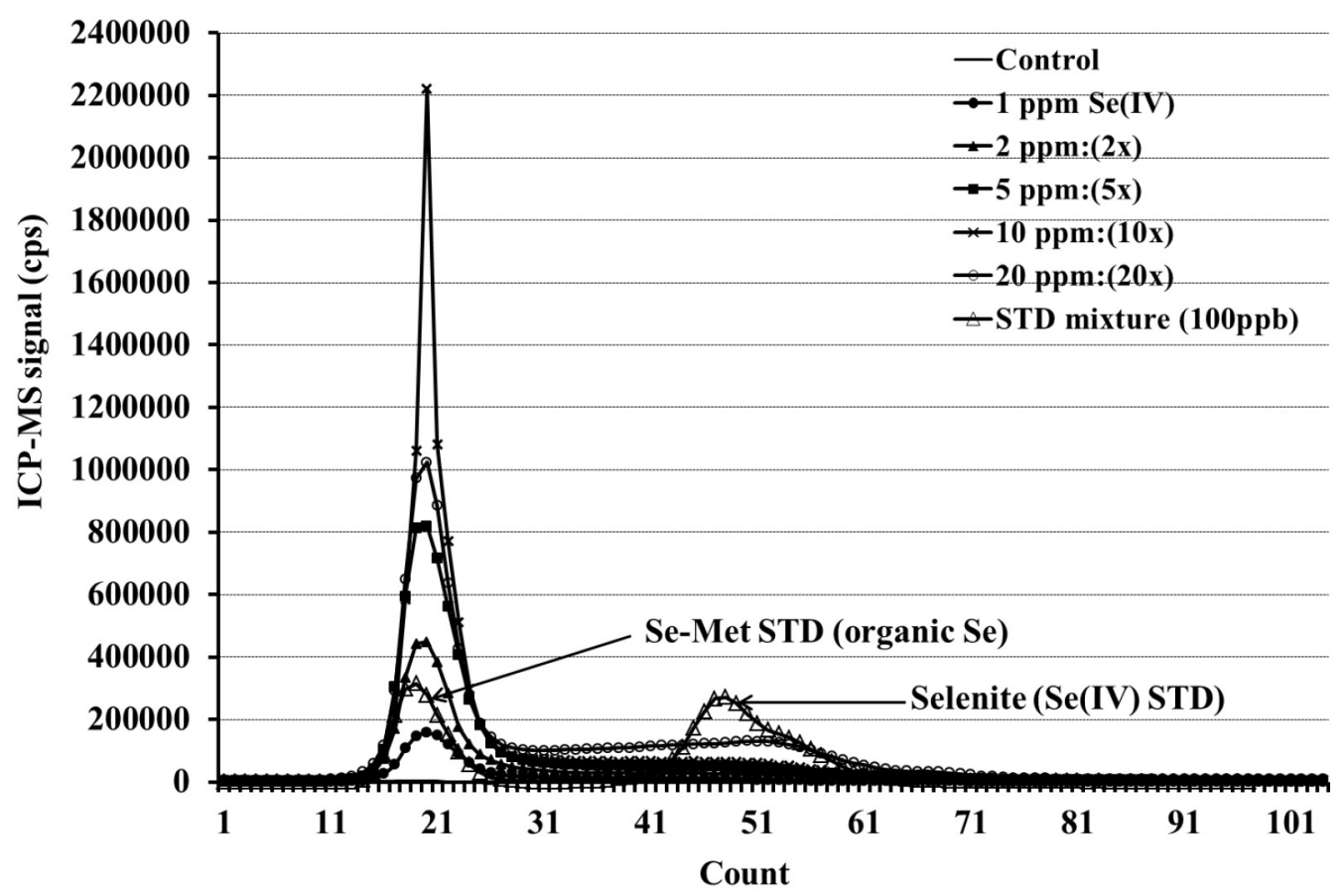

Fig. 8: Conversion of different concentrations of sodium selenite [Se(IV)] to organic form in cell fraction of $L$. acidophilus incubated in MRS media at $37^{\circ} \mathrm{C}$ for $24 \mathrm{hrs}$.

in the cultured media was converted to an organic form during the incubation period (24hr). However, The medium supplemented with $1 \mathrm{ppm}$ almost depleted from the inorganic Se (IV). On the other side, the bacterial cell fractions had higher concentration of organic Se (Fig. 8) compared to its corresponding cultured medium supernatant (Fig. 7).
Except for the medium supplemented with $20 \mathrm{ppm}$ $\mathrm{Se}$ (IV), the selenium was almost detected inside the bacterial cell in an organic form.

The bacterial cell fraction of the medium fortified with $1 \mathrm{ppm}$ Se (IV) contained no inorganic selenium which indicate a complete conversation of $\mathrm{Se}$ (IV) to organic form at that concentration or less. In 
this respect, Prokisch et al., (2008) stated that whey media cultivated with yoghurt culture $(S$. thermophilus and L. bulgaricus) and different concentrations of $\mathrm{Se}(\mathrm{IV})$ markedly increased the organic form of selenium in the supernatant. The bacterial culture consumed the inorganic Se and completely converted it to an organic form at concentration of $1 \mathrm{ppm}$ in the cultured media.
On contrast, L. acidophilus had weak ability to convert $\mathrm{Se}(\mathrm{VI})$ to an organic form compared to Se(IV). The data illustrated in Fig. (9) and Fig. (10) obviously show the remaining of high residual content of $\mathrm{Se}(\mathrm{VI})$ in the cultured medium supernatant (Fig. 9), however, all the Se detected in the cell fraction was in the organic form (Fig. 10). In conclusion, The obtained results indicate that $L$.

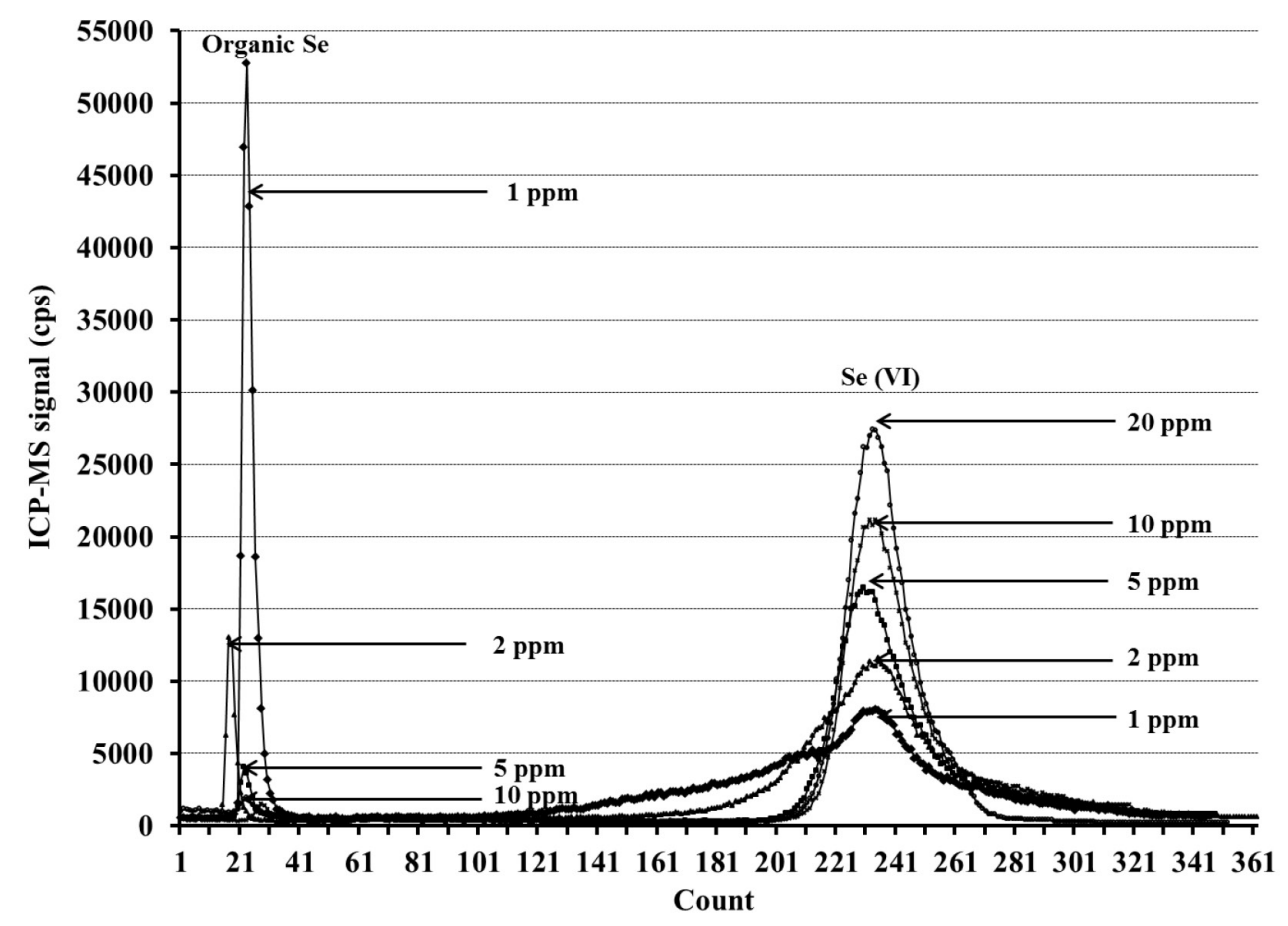

Fig. 9: Conversion of different concentrations of sodium selenate [Se(VI)] to organic form in MRS media supernatant incubated with $L$. acidophilus at $37^{\circ} \mathrm{C}$ for $24 \mathrm{hrs}$.

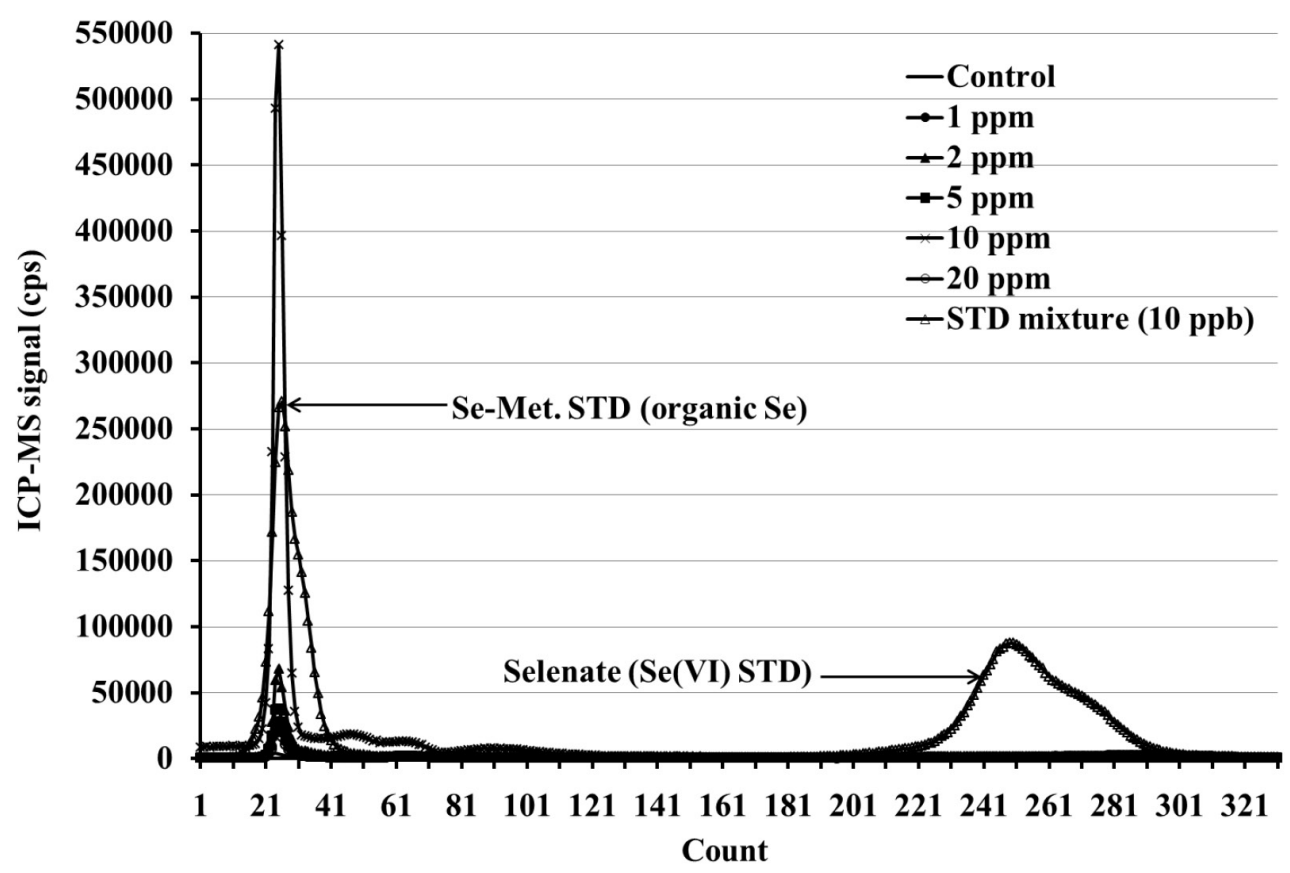

Fig. 10: Conversion of different concentrations of sodium selenate [Se(VI)] to organic form in cell fraction of $L$. acidophilus incubated in MRS media at $37^{\circ} \mathrm{C}$ for $24 \mathrm{hrs}$. 
acidophilus could be used as Se-enriched probiotic using $\mathrm{Se}(\mathrm{IV})$ or $\mathrm{Se}(\mathrm{VI})$ up to $20 \mathrm{ppm}$ with superior to $\mathrm{Se}(\mathrm{IV})$, or as a starter culture for producing Se rich fermented dairy foods using $\mathrm{Se}(\mathrm{IV})$ at a limit concentration of $1 \mathrm{ppm}$. Also, in higher SeIV concentration L. acidophilus produces SeNPs which may be applied in different applications, however still need more adequate research in this regard.

\section{REFERENCES}

Alzate, A., Cañas, B., Pérez-Munguí, S., Hernández-Mendoza, H., Pérez-Conde, C., Gutiérrez, A.M. \& Cámara, C. 2007. Evaluation of the inorganic selenium biotransformation in selenium-enriched yogurt by HPLC-ICPMS, Journal of Agricultural and Food Chemistry, 55: 9776-9783.

Alzate, A., Fernández-Fernández, A., Pérez-Conde, C., Gutiérrez, A. M. \& Cámara C. 2008. Comparison of biotransformation of inorganic seleniumby lactobacillus and saccharomyces in lactic fermentation process of yogurt and kefir. Journal of Agricultural and Food Chemistry, 56: 8728-8736.

Alzate, A., Pérez-Conde, M. C., Gutiérrez, A. M. \& Cámara, C. 2010. Selenium-enriched fermented milk: A suitable dairy product to improve selenium intake in humans. International Dairy Journal, 20: 761-769.

De-Man J., Rogosa M. \& Sharpe M., 1960. A medium for the cultivation of lactobacilli. Journal of Applied Bacteriology, 23:130-135.

Diowksza, A., Ambroziak, W. \& Wlodarczyk, M. 1999. Investigation of the ability of selenium accumulation by lactic acid bacteria of Lactobacillus species and yeast Saccharomyces cerevisiae. Journal of Food and Nutrition Sciences, 8: 17-22.

Elsokkary, I. H. 1980. Selenium Distribution, Chemical Fractionation and Adsorption in some Egyptian Alluvial and Lacustrine Soils. Journal of Plant Nutrition and Soil Science, 143: $74-83$.

Eszenyi, P., Sztrik, A., Babka, B. \& Prokisch, J. 2011. Elemental, nano-sized (100-500 nm) selenium production by probiotic lactic acid bacteria. International Journal of Bioscience, Biochemistry and Bioinformatics, 1: 148-152.

Galano, E., Mangiapane, E., Bianga, J., Palmese, A., Pessione, E., Szpunar, J., Lobinski, R. \&
Amoresano, A. 2013. Privileged incorporation of selenium as selenocysteine in lactobacillus reuteri proteins demonstrated by selenium-specific imaging and proteomics, Mol. Cell. Proteomics, 12: 2196-2204.

Hussein, L. \& Bruggeman J. 1999. Selenium analysis of selected Egyptian foods and estimated daily intakes among a population group. Food Chemistry, 65: 527-532.

Jansson, H. \& Sillanpää, M. 1992. Status of cadmium, lead, cobalt and selenium in soils and plants of thirty countries. FAO soil Bulletin, 65: 127-131.

Kurek, E., Ruszczyńska, A., Wojciechowski, M., Łuciuk, A., Michalska-Kacymirow, M., Motyl, I. \& Bulska, E. 2016. Bio-transformation of selenium in Se-nriched bacterial strains of Lactobacillus casei. Roczniki Panstwowego Zakladu Higieny, 67: 253-262.

Loualeche, H., Bracquart, P., Saulnier, F., Desmazeaud, M. \& Linden, G. 1993 Carbon dioxide effects on the growth and metabolites of morphological variants of Streptococcus thermophilus. Journal of Dairy Science, 76: 3683-3689.

Nagy, G. Pinczes, G., Pinter, G., Pocsi, I., Prokisch, J. \& Banfalvi, G. 2016. In situ electron microscopy of lactomicroselenium particles in probiotic bacteria. International Journal of Molecular Sciences, 17: 1-8.

Palomo, M., Gutiérrez, A. M., Pérez-Conde, M. C., Cámara, C. \& Madrid Y. 2014 Se metallomics during lactic fermentation of Seenriched yogurt. Food Chemistry, 164: 371379.

Peng, D., Zhang, J., Liu, Q. \& Taylor, E. W. 2007. Size effect of elemental selenium nanoparticles (Nano-Se) at supranutritional levels on selenium accumulation and glutathione S-transferase activity. Journal of Inorganic Biochemistry, 101: 1457-1463.

Pescuma, M., Gomez-Gomez, B., Perez-Corona, T., Font, G., Madrid, Y. \& Mozzi, F. 2017. Food prospects of selenium enriched-Lactobacillus acidophilus CRL 636 and Lactobacillus reuteri CRL 1101. Journal of Functional Foods, 35: 466-473.

Pophaly, S. D., Poonam, Singh, P., Kumar, H., Tomar, S. K. \& Singh, R. 2014. Selenium enrichment of lactic acid bacteria and bifi- 
dobacteria: A functional food perspective. Trends in Food Science and Technology 39: 135-145.

Prokisch, J. \& Zommara, M. A. 2011. Process for producing elemental selenium nanospheres, United States Patent 20100189634.

Prokisch, J., Széles, É., Kovács, B., Daróczy, L. \& Zommara, M. 2008. Formation of metal selenium nanospheres in bacteria: Is it a possible detoxification mechanism? Cereal Research Communications, 36. Suppl. 5, 947-951.

Rajasree, S. R. R. \& Gayathri, S. 2015. Extracellular biosynthesis of selenium nanoparticles using some species of lactobacillus. Indian Journal of Marine Science, 43: 766-775.
Zhang, J., Wang, H., Bao, Y. \& Zhang L. 2004. Nano red elemental selenium has no size effect in the induction of seleno-enzymes in both cultured cells and mice. Life Science, 75: 237-244.

Zommara, M. A., Prokisch, J., Széles, E. \& Zoltán, G. 2007. Utilization of whey from the manufacture of Kareish cheese enriched with organic selenium in bread making. The 10th International Conference for Dairy Science and Technology, 549-564, 19-21, November, Cairo.

Zommara, M. \& Prokisch, J. 2015. Selenium rich yoghurt: Bio-fortification for better health. Egyptian Journal of Dairy Science, 43: 159167.

\title{
تحويل السيلنيوم غير العضوى إلى عضوى باستخلام مزارع Lactobacillus acidophilus
}

\author{
محسن عبد العزيز زمارها ، جوزيف بروكثى
}

'قسم علوم الألبان - كلية الزراعة - جامعة كفر الشيخ - كفر الشيخ رقم بريلى

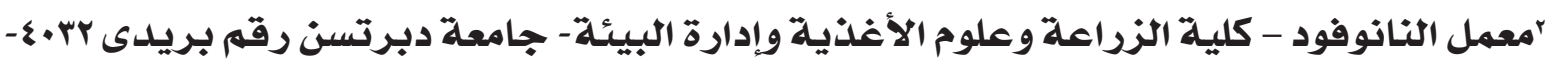

$$
\text { دبرتسن - المجر }
$$

لقد تم دراسة التحويل البيولوجى للسيلنيوم فى نوعين من أملاح السيلنيوم غير العضوى هما صوديوم

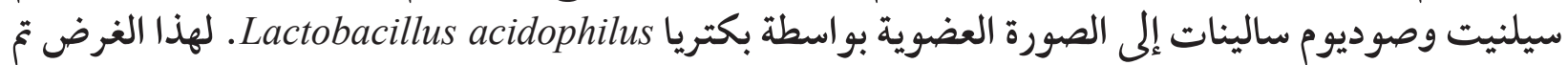

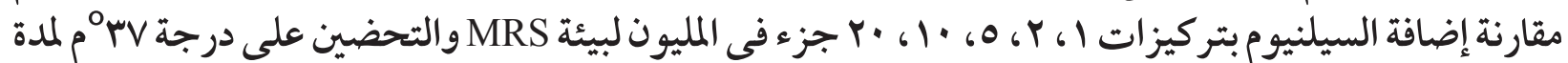

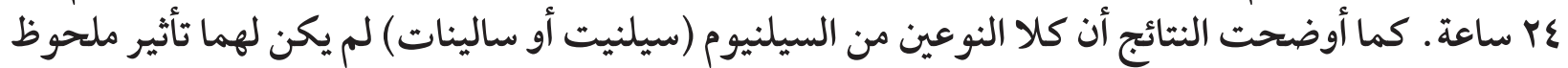

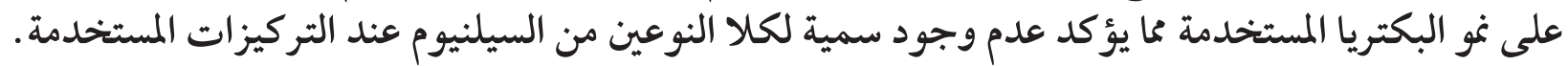

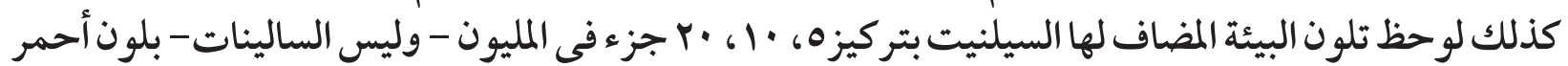

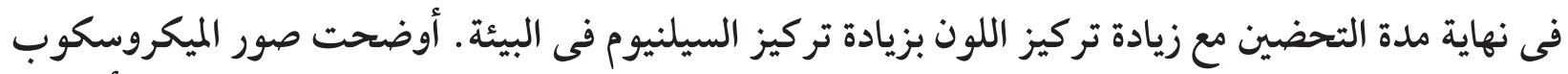

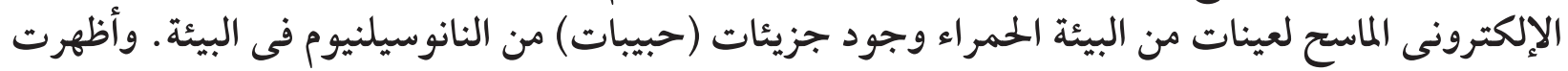

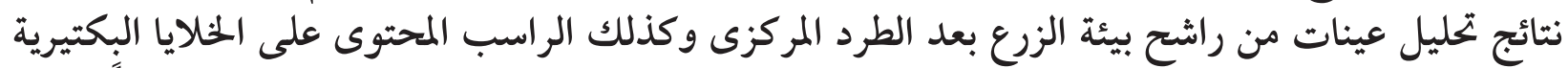
بواسطة جهاز HPLC-ICP-MS أن معدلات تحويل السيلنيوم غير العضوى للصورة العضوية كان كبيراً بشكل

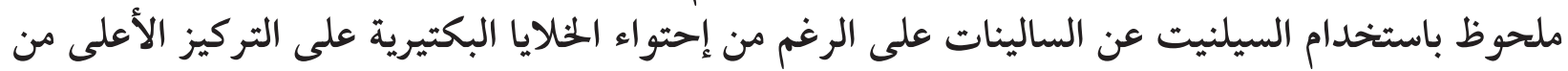

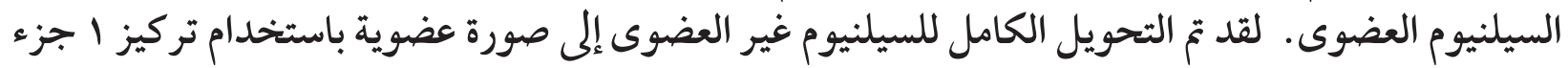
فى المليون من ملح السيلنيت.

Lactobacillus acido- النتائج المتحصل عليها توضح إمكانية إنتاج منتجات لبنية متخمرة بواسطة بكتريات philus 